\title{
PENINGKATAN KEMAMPUAN MENULIS TEKS PROSEDUR DENGAN MODEL PEMBELAJARAN PAIR CHECKS
}

\author{
Ana \\ SMPN 1 Sengah Temila \\ Email:24102015@gmail.com
}

\begin{abstract}
This study is aimed to describe the improvement of writing abiliy on procedure text by using pair checks learning model at the eighth grade students of SMP Negeri 1 Sengah Temila. The method used in this research was descriptive method. Descriptive method is concerned with developing or giving explanations of social phenomena towards subject that being observed. The techniques used in this research were observaion, documentary study, and test. The result of writing ability on prosedure text by using pair checks learning model at the eighth grade students of SMP Negeri 1 Sengah Temila in the firstcycle was 72, 88\% and in the second cycle, the students' score was 80, 45\%. It can be concluded that the implementation of pair checks learning model improved students' writing ability on procedure text at the eighth grade students of junior high school in SMP Negeri 1 Sengah Temila.
\end{abstract}

Keywords: Writing Ability, Pair Checks, Students Outcom

\section{PENDAHULUAN}

Menulis merupakan kegiatan

penyampaian pesan seperti gagasan, perasaan dan informasi secara tertulis kepada orang lain. Sebagai satu bentuk komunikasi verbal, menulis melibatkan unsur penulis sebagai penyampai pesan, pesan atau isi tulisan, saluran tulisan dan pembaca sebagai penerima pesan. Menurut Akhadiah (1998:16) menulis adalah kegiatan penyampaian pesan (gagasan, perasaan, dan informasi) secara tertulis kepada pihak lain. Sebagai suatu keterampilan bahasa menulis merupakan kegiatan yang kompleks. Kompleksitas terdapat pada kemampuan penulis

menyusun dan mengorganisasikan isi tulisannya serta menuangkan dalam formulasi ragam bahasa tulis dan konveksi penulisan lainnya. Tarigan (2008:3) menjelaskan menulis merupakan suatu keterampilan berbahasa yang dipergunakan untuk berkomunikasi secara tidak langsung, tidak secara tatap muka dengan orang lain.

Menulis memiliki banyak manfaat sebagai pengembangan mental, intelektual, dan sosial seseorang. Menulis dapat menyumbang kemampuan, mengembangkan inisiatif, kreativitas, menumbuhkan keberanian, merangsang kemauan, dan kemampuan mengumpulkan informasi. Meskipun demikian, banyak orang yang tidak menyukai tulis menulis, satu di antara penyebabnya tidak memiliki bakat. Alasan keengganan menulis seperti itu tidak terlepas dari pengalaman menulis yang dialami seseorang ketika di sekolah.

Kurangnya model dan munculnya mitos atau miskonsepsi tentang menulis dan 
pembelajarannya semakin memperparah keadaan. Mitos itu beranggapan bahwa menulis itu mudah dan harus sekali jadi. Menulis itu lebih mementingkan unsur mekanik dari pada isi, dan orang yang tidak suka menulis, tidak memiliki pengalaman tentunya tidak mempunyai kemampuan dalam menulis.

Menulis sebagai aktivitas berbahasa tidak bisa dilepas dari kegiatan berbahasa lainnya. Apa yang diperoleh melalui menyimak, membaca dan berbicara akan memberi masukan berharga untuk kegiatan menulis. Meskipun demikian, menulis merupakan suatu aktivitas berbahasa tulis memiliki perbedaan, terutama dengan kegiatan berbahasa lisan. Perbedaan seperti itu menyangkut kecaraan serta konteks dan hubungan antar unsur yang terlibat, yang berimplikasi pada ragam bahasa yang digunakan ketika penulis melakukan aktivitas tulisnya.

Teks prosedur (procedure) merupakan teks yang berisi tujuan dan langkah-langkah yang harus diikuti agar suatu pekerjaan dapat dilakukan. Di dalam teks prosedur diuraikan bagaimana sesuatu dapat dikerjakan melalui serangkaian langkah-langkah atau tindakan. Teks prosedur adalah jenis teks yang dapat dijumpai di sekitar kita. Tujuan komunikatif teks prosedur adalah memberi petunjuk cara melakukan sesuatu melalui serangkaian tindakan atau langkah. (Kementerian Pendidikan dan Kebudayaan Republik Indonesia Kelas VIII, 2014: 84). Dalam kehidupan sehari-hari, kita menggunakan teks prosedur untuk memberikan petunjuk agar seseorang dapat melakukan suatu pekerjaan secara tepat. Agar kegiatan dapat secara tepat dan akurat serta memperoleh hasil maksimal, diperlukan prinsip-prinsip menyajikan teks prosedur.

\section{METODE}

Berdasarkan tujuan penelitian, metode yang digunakan dalam penelitian ini adalah metode deskriptif. Metode ini memberikan gambaran atau uraian atas suatu keadaan dengan jelas terhadap subjek yang diteliti. Menurut Zuldafrial (2012:52) menyatakan bahwa " metode deskriptif adalah suatu metode yang dipergunakan didalam memecahkan masalah penelitian dengan cara menggambarkan atau melukiskan keadaan subjek atau objek penelitian pada saat sekarang berdasarkan fakta-fakta yang tampak atau sebagaimana adanya".

Sugiyono (2014:3), menyatakan "Secara umum metode penelitian diartikan sebagai cara ilmiah untuk mendapatkan data dengan tujuan dan kegunaan tertentu". Cara ilmiah berarti kegiatan penelitian itu didasarkan pada ciri-ciri keilmuan, yaitu rasional, empiris, dan sistematis. Rasional berarti kegiatan penelitian itu dilakukan dengan cara-cara yang masuk akal, sehingga terjangkau oleh penalaran manusia. Empiris berarti caracara yang dilakukan itu dapat diamati oleh indera manusia, sehingga orang lain dapat mengamati dan mengetahui cara-cara yang digunakan. Sistematis artinya, proses yang digunakan dalam penelitian itu menggunakan langkah-langkah tertentu yang bersifat logis. Bentuk penelitian yang digunakan peneliti berbentuk kualitatif. Penelitian kualitatif merupakan penelitian yang digunakan untuk menemukan, menggambarkan, dan menjelaskan kualitas dari pengaruh sebuah model pembelajaran. Fokus penelitian ini pada aspek perencanaan, pelaksanaan, dan hasil pembelajaran menulis teks prosedur dengan menggunakan metode pair checks pada siswa kelas VIII B SMP Negeri 1 Sengah Temila.

Data dalam penelitian ini, yaitu instrumen pembelajaran yang digunakan berupa Rencana Pelaksanaan Pembelajaran (RPP) pada pembelajaran menulis teks prosedur, hasil observasi pelaksanaan pembelajaran, dan hasil tes menulis teks prosedur pada siswa kelas VIII 
SMP Negeri 1 Sengah Temila Kabupaten Landak. Sumber data dalam penelitian ini, yaitu guru dan siswa yang melakukan proses pembelajaran menulis teks prosedur siswa di kelas VIII SMP Negeri 1 Sengah Temila Kabupaten Landak. Siswa kelas VIII yang berjumlah 35 yang terdiri 17 laki-laki dan 18 perempuan.

Tempat penelitian ini dilakukan di SMP Negeri 1 Sengah Temila Kecamatan Sengah Temila Kabupaten Landak. Alasan peneliti memilih sekolah ini karena peneliti bekerja sebagai guru mata pelajaran bahasa Indonesia di sekolah ini dan dengan mudah dapat melihat perkembangan anak didik.

Adapun teknik pengumpulan data yang digunakan dalam penelitian ini berupa teknik tes dan nontes yaitu 1) teknik observasi dilakukan melalui lembar pedoman observasi yang digunakan untuk pengumpulan data tentang aktivitas guru dan siswa dalam proses belajar mengajar menggunakan model pair check. 2) Data dokumentasi yang digunakan dalam penelitian ini berupa silabus, rencana pelaksanaan pembelajaran (RPP) dan gambar/foto. Dokumentasi merupakan data yang penting sebagai bukti terjadinya suatu peristiwa, dalam penelitian ini peneliti menggunakan dokumentasi foto sebagai data nontes. Data yang diambil melalui dokumentasi foto juga memperjelas data lain yang hanya dideskripsikan melalui tulisan dan angka. Sebagai data penelitian, hasil dokumentasi gambar/foto selanjutnya dideskripsikan sesuai keadaan dan dipadupadankan dengan data-data yang lain. 3) teknik tes dengan menggunakan soal untuk mengukur hasil kemampuan menulis teks prosedur. Alat pengumpul data adalah 1) Lembar observasi. Langkah pengumpulan data menggunakan lembar observasi: (a) Menentukan tujuan dan fungsi kegiatan observasi. (b) Mencatat data yang diperlukan dan menyesuaikannya dengan tujuan / fungsi observasi. (c) Melakukan survei tempat dan melanjutkan observasi. (d) Menemui narasumber untuk wawancara sebagai bukti penguat dan sumber acuan ( referensi ). (e) Mencatat hasil observasi. Untuk memperoleh hasil observasi yang baik, seorang pengamat yang hendak melakukan observasi sebaiknya memperhatikan prinsip - prinsip pengamatan yaitu: data harus dilakukan dengan cermat, jujur, bertanggung jawab terhadap permasalahan, objektif, dan terfokus pada objek yang diteliti. 2) Dokumen dan RPP dengan menggunakan alat seperti kamera untuk mengambil video dan foto dalam menggumpulkan data untuk mendapatkan hasil yang maksimal yang mengambarkan situasi dan kondisi kegiatan, RPP terlampir. 3) Tes, Langkah-langkah pengumpulan data menggunakan tes sebagai berikut.

a) Menentukan persiapan dan tujuan mengadakan tes.

b) Pemilihan materi dan pembatasan terhadap bahan yang akan diteskan.

c) Menentukan bentuk dan jenis tes.

d) Merumuskan kompetensi dasar dari tiap bagian bahan.

e) Menderetkan semua KD dalam tabel persiapan yang memuat pula aspek tingkah laku terkandung dalam KD itu. Tabel ini digunakan untuk mengadakan identifikasi terhadap tingkah laku yang dikehendaki, agar tidak terlewati.

f) Menyusun tabel spesifikasi yang memuat pokok materi, aspek berpikir yang diukur beserta imbangan antara kedua hal tersebut. Uraian secara terinci tentang tabel spesifikasi, akan disajikan pada bab berikutnya. 
g) Menentukan jumlah butir tes dan menuliskan butir-butir soal, didasarkan atas KD yang sudah dituliskan pada tabel $\mathrm{KD}$ dan aspek tingkah laku yang dicakup.

h) Menentukan skor.

i) Membuat kisi-kisi.

j) Menyusun tes berdasarkan kisi-kisi.

4) Peneliti mengumpulkan data penelitian dari hasil observasi pelaksanaan pembelajaran selama dua siklus yang dilaksanakan. 5) Peneliti mengumpulkan data hasil tes siswa selama dua siklus dari pelaksanaan pembelajaran dengan model pair checks.

Peneliti melakukan Penelitian Tindakan Kelas yang terdiri dari dua siklus. Setiap siklus terdiri dari empat tahapan (Arikunto, 2015:143) yaitu perencanaan, pelaksanaan, observasi, dan refleksi. Penelitian ini menggunakan model pair checks dalam pembelajaran menulis teks prosedur.

\section{HASIL DAN PEMBAHASAN Hasil Penelitian}

Analisis data yang dilakukan oleh peneliti yaitu mendeskripsikan peningkatan kemampuan menulis teks prosedur dengan model pembelajaran pair checks pada siswa kelas VIII SMP Negeri 1 Sengah Temila Kabupaten Landak. Pembelajaran yang dilakukan di dalam kelas tidak dapat dilakukan secara serta merta atau tiba-tiba tanpa adanya perencanaan. Perencanaan ini di kenal dengan rencana pelaksanaan pembelajaran (RPP). Perencanaan pembelajaran terdapat dalam rencana pelaksanaan pembelajaran (RPP) dibuat berdasarkan silabus. RPP yang disusun diantaranya memuat; kompetensi inti, kompetensi dasar, indikator, materi pembelajaran, kegiatan pembelajaran, metode pembelajaran, dan penilaian. Berikut ini dijelaskan hal tersebut.

Kompetensi inti; 1. Menghargai dan menghayati ajaran agama yang dianutnya. 2 . Menghargai dan menghayati perilaku jujur, disiplin, tanggungjawab, peduli (toleransi, gotong royong), santun, percaya diri, dalam berinteraksi secara efektif dengan lingkungan sosial dan alam dalam jangkauan pergaulan dan keberadaannya. 3. Memahami pengetahuan (faktual, konseptual, dan prosedural) berdasarkan rasa ingin tahunya tentang ilmu pengetahuan, teknologi, seni, budaya terkait fenomena dan kejadian tampak mata. 4. Mencoba, mengolah, dan menyaji dalam ranah konkret (menggunakan, mengurai, merangkai, memodifikasi, dan membuat) dan ranah abstrak (menulis, membaca, menghitung, menggambar, dan mengarang) sesuai dengan yang dipelajari di sekolah dan sumber lain yang sama dalam sudut pandang/teori. Kompetensi dasar; Menyusun teks cerita moral/fabel, ulasan, diskusi, prosedur, dan cerita biografi sesuai dengan karakteristik teks yang akan dibuat baik secara lisan maupun tulisan. Indikator; Menulis teks prosedur "Cara Memasak Nasi Goreng" secara urut dan logis. Materi pembelajaran; Teks prosedur. Metode pembelajaran yang digunakan pada siklus I ini adalah tanya jawab, penugasan, dengan pendekatan saintifik. Sedangkan, model pembelajaran yang digunakan pair checks, dan media yang digunakan contoh teks prosedur. Peningkatan pembelajaran menulis teks prosedur dengan model pair checks ini dilakukan di SMP Negeri 1 Sengah Temila semester ganjil tahun pelajaran 2016/2017. Penelitian dilakukan di kelas VIII B dengan jumlah siswa 35 siswa, yang terdiri dari 17 laki-laki dan 18 perempuan.

Data kuantitatif yang didapat oleh peneliti sebelum melakukan penelitian tindakan kelas, 
kemampuan siswa kelas VIII B dalam menulis teks prosedur masih rendah, nilai rata-rata yang diperoleh adalah 69.94 dan siswa yang telah mencapai tingkat ketuntasan belajarnya (dengan memeroleh nilai >70) baru mencapai $37,14 \%$ dengan jumlah siswa sebanyak 13 orang. Sedangkan siswa yang belum tuntas (dengan memeroleh nilai < 70) sebanyak 22 orang dengan persentase sebesar $62,86 \%$.

Selain rata-rata yang belum mencapai KKM, pada pembelajaran yang dilakukan oleh peneliti, menunjukkan siswa kurang termotivasi dalam mengikuti pembelajaran menulis teks prosedur, karena pembelajaran dilakukan secara konvensional. Peneliti hanya memberikan informasi singkat mengenai materi menulis teks prosedur dan memberi latihan kepada siswa untuk menulis teks prosedur secara kelompok. Hal tersebut menyebabkan siswa kurang aktif dan mengalami kesulitan dalam mengembangkan menulis teks prosedur secara urut dan logis sesuai dengan struktur menulis teks prosedur. Kesulitan ini dapat diminimalisir dengan menggunakan model pembelajaran pair checks.

Model pair checks sangat tepat digunakan dalam pembelajaran menulis teks prosedur. Model ini menuntut siswa untuk lebih mandiri dan bertanggung jawab dalam mengerjakan tugas dalam kelompoknya. Karena dalam menulis teks prosedur tidak hanya mengungkapkan kata-kata menjadi kalimat secara mudah tetapi memperhatikan susunan dan urutan yang sesuai dengan penulisan teks prosedur.

Untuk mengatasi permasalahan di atas, penulis melakukan Penelitian Tindakan Kelas yang terdiri dari dua siklus. Setiap siklus terdiri dari empat tahapan (Arikunto, 2015:143) yaitu perencanaan, pelaksanaan, observasi, dan refleksi. Penelitian ini menggunakan model pair checks dalam pembelajaran menulis teks prosedur.

Penelitian Tindakan Kelas ini dilaksanakan di ruang kelas, dengan pencahayaan atau penerangan yang baik dan hiasan kelas serta papan nama setiap siswa tergantung di atas tempat duduknya yang menambah semarak ruangan kelas. Sehingga membuat siswa betah berada di dalam kelas.

Siklus ke-1 hari Jumat, 21 Oktober 2016 pada jam ke-1 dan ke-2 dilakukan pembelajaran menulis teks prosedur dengan menggunakan pair checks.

Siklus ke-2 dilaksanakan pada tanggal 24 Oktober 2016. Perencanaan pembelajaran dilakukan pada hari Sabtu, tanggal 22 Oktober 2016. Pengamatan dilakukan pada tanggal dan hari yang sama baik siklus ke-1 maupun siklus ke-2. Refleksi dilaksanakan pada hari Kamis, tanggal 27 Oktober 2016. Penelitian ini dilakukan secara kolaborasi dengan rekan sejawat peneliti yaitu guru bahasa Indonesia di SMP Negeri 1 Sengah Temila.

\section{Pembahasan \\ Penelitian Siklus 1}

Siklus I terdiri dari empat tahap, yaitu: perencanaan, pelaksanaan, observasi, dan refleksi. Untuk keterangan lebih lengkap pada pelaksanaan Penelitian Tindakan Kelas pada siklus sebagai berikut.

\section{Perencanaan (planning) Pembelajaran}

Hari Kamis, tanggal 20 Oktober 2016, peneliti telah menginformasikan bahwa pelajaran bahasa Indonesia pada hari Jumat, tanggal 21 Oktober 2016 jam ke-1 dan ke-2 akan dilakukan pembelajaran menulis teks prosedur dengan menggunakan model pair checks. Jadi, pada tanggal 21 Oktober 2016 tersebut saat 
pelaksanaan pembelajaran siswa sudah siap belajar serta dapat memperhatikan dengan baik langkah-langkah model pair checks dalam menulis teks prosedur.

Sebelum melaksanakan rencana pembelajaran pada siklus I, peneliti berdiskusi dengan guru mata pelajaran bahasa Indonesia mengenai pembelajaran menulis teks prosedur menggunakan model pair checks.

\section{Pelaksanaan (action) Pembelajaran}

Tindakan siklus I dilaksanakan hari Jumat, tanggal 21 Oktober 2016 pada jam pelajaran 12, (alokasi waktu 2 x 40 menit) siswa dalam keadaan siap menerima pelajaran karena keadaan masih pagi dan mereka terlihat bersemangat sehingga suasana pembelajaran dikatakan kondusif.

\section{Pengamatan (observing) \\ Pembelajaran}

Observasi atau pengamatan ini dilakukan olah peneliti terhadap kinerja siswa, sedangkan observasi atau pengamatan kinerja guru dalam pelaksanaan pembelajaran dilakukan oleh guru bahasa Indonesia (observer) terhadap guru/pelaku pelaksanaan pembelajaran (peneliti) dengan memberi tanda ceklis $(\sqrt{ })$ pada setiap komponen kegiatan pembelajaran yang terdapat dalam lembar observasi pelaksanaan pembelajaran.

Pelaksanaan observasi ini waktu pelaksanaan pembelajaran menulis teks prosedur dengan model pair checks pada pertemuan siklus I yang berlangsung pada hari Jumat, tangal 21 Oktober 2016 pukul 07.00 - 08.20 WIB (jam ke 1-2). Fokus observasi adalah situasi pelaksanaan pembelajaran, kegiatan yang dilaksanakan guru dan keaktifan siswa dalam proses pembelajaran menulis teks prosedur dengan model pair checks.

\section{Refleksi siklus 1}

Refleksi digunakan untuk menentukan dan menyimpulkan apakah pelaksanaan pada siklus I masih perlu dilanjutkan atau tidak. Berdasarkan data yang diperoleh dari hasil observasi prose pelaksanaan pembelajaran pada siklus I, terdapat peningkatan kemampuan siswa dalam menulis teks prosedur. Namun peneliti merasa bahwa penggunaan model pair checks belum berpengaruh pada kemampuan siswa menulis teks prosedur. Masih perlu ditingkatkan dan kemampuan siswa dalam menulis teks prosedur masih kurang, terutama penggunaan tanda baca, kosa kata dan langkah-langkah dan tentunya hal ini karena pengaruh model pembelajaran pair checks belum berpengaruh dan perlu bimbingan lagi dari peneliti dan kolaborator serta pencapaian indikator belum memenuhi kinerja yang diharapkan.

Berdasarkan hasil analisis dan refleksi di atas, tindakan pada siklus I belum mencapai hasil yang optimal yaitu belum mencapai $75 \%$, yaitu $71,42 \%$ atau sekitar 25 orang yang nilainya mencapai KKM dengan rata-rata $72,88 \%$ yang menurut peneliti masih perlu dilanjutkan. Ketidakpuasan peneliti terhadap hasil observasi proses pembelajaran pada siklus I itu kemudian peneliti sampaikan pada guru mata pelajaran yang bersangkutan. Setelah melalui hasil unjuk kerja siswa pada siklus I, maka guru dan peneliti sepakat untuk melanjutkan penelitian ini pada siklus II dengan materi pembelajaran dan model pembelajarn yang sama.

\section{Penelitian Siklus II \\ Perencanaan}

Perencanaan pada siklus II dilaksanakan pada hari Senin, 24 Oktober 2016. Perencanaan pembelajaran disusun bersama kolaborator. Pada siklus ini penulisan teks prosedur lebih spesifik lagi agar wawasan siswa dapat lebih luas lagi 
dengan penentuan topik yang sama sehingga dapat memudahkan peneliti dalam melakukan penilaian dari segi aspek tanda baca, kosa kata, dan langkah-langkah penulisan teks prosedur. Topik pada teks prosedur siklus II ini adalah cara memasak mie. Rencana pembelajaran dan perangkat mengajar dilakukan dengan tetap menggunakan model pair checks. Peneliti juga menyiapkan pedoman observasi yang akan digunakan kolaborator untuk mengamati kegiatan pembelajaran yang dilakukan guru dan siswa dalam menggunakan model pair checks pada pembelajaran menulis teks prosedur.

\section{Pelaksanaan}

Pelaksanaan tindakan kelas ini dilaksanakan hari Senin, 24 Oktober 2016, di ruangan kelas VIII B pukul 11.00 - 12.20 WIB. Alokasi waktu yang digunakan 2 x 40 menit dengan langkah-langkah pelaksanaan tindakan yang dilakukan dalam proses pembelajaran pada siklus II.

\section{Pengamatan (observing) Pembelajaran}

Pelaksanaan observasi waktu proses pembelajaran menulis teks prosedur dengan model pair checks berlangsung pada hari Senin, 24 Oktober 2016 pukul 11.00 - 12.20 WIB (jam ke 6-7). Pengamatan dilakukan pada:

1. Pengamatan terhadap kemampuan guru merencanakan kegiatan pembelajaran menulis teks prosedur menggunakan model pair checks. Permasalahan yang ada pada siklus I sudah dapat ditangani dengan baik pada siklus II. Kegiatan pendahuluan, inti, dan penutup sudah tercantum dengan jelas pelaksanaan yang dilaksanakan pada pembelajaran siklus II. Sebagian besar aspek yang dinilai dalam RPP yang dibuat sudah mencapai kriteria sangat baik, karena dari 16 aspek yang dinilai terdapat 15 aspek kriteria sangat baik, dan 1 aspek kriteria baik dengan persentase $3,94 \%$ (sangat baik).
2. Pengamatan terhadap pelaksanaan kegiatan pembelajaran menulis teks prosedur dengan model pair checks. Selama proses kegiatan belajar tidak ditemukan kendala yang signifikan. Semua kegiatan terlaksana sesuai dengan alokasi waktu yang telah ditentukan. Pelaksanaan proses pembelajaran telah dilakukan guru sesuai dengan RPP yang disusun bersama peneliti.

3. Pengamatan terhadap kemampuan guru melaksanakan pembelajaran menulis teks prosedur dengan model pair checks.

Sebagian besar aspek yang dinilai dalam pelaksanaan pembelajaran sudah mencapai kriteria sangat baik karena dari 25 aspek yang dinilai, terdapat 23 aspek kriteria sangat baik, dan 2 aspek kriteria baik. Jadi, persentase nilai pelaksanaan pembelajaran siklus II adalah 3,35\% kategori baik.

4. Pengamatan terhadap sikap siswa dalam mengikuti kegiatan pembelajaran menulis teks prosedur dengan menggunakan model pair checks. Pengamatan terhadap sikap siswa terhadap proses pembelajaran menulis teks prosedur dengan model pair checks dilaksanakan oleh peneliti sendiri dan dibantu oleh guru yang melakukan tindakan menggunakan lembar observasi yang telah dipersiapkan oleh peneliti.

\section{Refleksi}

Refleksi digunakan untuk menentukan dan menyimpulkan apakah pelaksanaan pada siklus II masih perlu dilanjutkan atau tidak. Berdasarkan data yang diperoleh dari hasil observasi proses pelaksanaan pembelajaran pada siklus II, terdapat peningkatan kemampuan siswa dalam menulis teks prosedur yaitu $80,85 \%$ pencapaian ketuntasan klasikal sebesar $80 \%$ atau $100 \%$ tuntas. Peneliti merasa bahwa penggunaan model pair checks sudah berpengaruh pada kemampuan siswa menulis teks prosedur. Penggunaan model pair checks ini dapat 
membantu siswa yang semula masih tidak yakin terutama penggunaan tanda baca, kosa kata dan langkah-langkah. Setelah dilakukan pembimbingan oleh peneliti dan kolaborator kemampuan menulis teks prosedur siswa semakin meningkat. Adapun yang masih mengalami kendala atau hambatan dalam menulis teks prosedur diberikan tugas atau remedi.

\section{SIMPULAN DAN SARAN \\ Simpulan}

Satu model pembelajaran yang digunakan oleh peneliti untuk meningkatkan kemampuan menulis teks prosedur adalah model pair checks. Untuk melaksanakan pembelajaran model pair checks ini dilakukan perencanaan, pelaksanaan, dan hasil yang didapatkan dari pelaksanaan yang diterapkan. Hasil penelitian kemampuan menulis teks prosedur dengan model pembelajaran pair checks pada siswa kelas VIII B SMP Negeri 1 Sengah Temila Kabupaten Landak pada siklus 1 adalah 72,88\% dan pada siklus II menjadi $80,85 \%$. Peningkatan dari siklus I ke siklus II yaitu 7,97\%. Berdasarkan nilai yang diperoleh siswa dengan nilai terendah 75 dan tertinggi 88, maka ketuntasan nilai siswa yang berjumlah 35 orang mencapai KKM menjadi $100 \%$. Hal ini menunjukkan bahwa model pembelajaran yang digunakan dapat meningkatkan kemampuan menulis teks prosedur pada siswa kelas VIII.

\section{Saran}

Penelitian dapat meningkatkan hasil belajar siswa pada mata pelajaran bahasa Indonesia khususnya kemampuan menulis teks prosedur. Saran yang diberikan peneliti dengan melakukan penelitian ini adalah: 1) Pada pembelajaran menulis teks prosedur sebaiknya lebih difokuskan pada keterampilan menulis teks prosedur daripada teori tentang pembelajaran menulis teks prosedur. 2) Guru sebaiknya dapat mengembangkan model pembelajaran yang beragam lagi sehingga siswa tidak merasa bosan dan siswa lebih bersemangat dalam belajar. 3) Dalam kerja kelompok siswa lebih komunikatif dan saling membantu serta tidak mengandalkan satu orang yang bekerja. 4) Bimbingan dari guru kepada siswa yang bekerja perlu dilakukan secara kontinyu sehingga dapat memicu aktivitas siswa dalam kerja kelompok. 5) Pujian (reward) dari guru yang ditujukan kepada siswa yang dapat menyelesaikan tugasnya dengan baik dapat membuat siswa semakin termotivasi. Bagi siswa yang belum berhasil tetap diberikan dorongan, semangat untuk lebih baik lagi dalam pembelajaran selanjutnya.

\section{DAFTAR RUJUKAN}

Akhdiah, Sabarti, dkk. 1998. Menulis

1. Jakatra: Universitas Terbuka.

Arikunto, Suharsimi, dkk. 2015. Penelitian

Tindakan Kelas (Edisi revisi). Jakarta:

PT. Bumi Aksara.

Sugiyono. 2014. Metode Penelitian

Pendidikan Pendekatan

Kuantitatif, Kualitatif

Dan $\boldsymbol{R} \& \boldsymbol{H}$. Bandung: Alfabeta.

Tarigan, Hendry Guntur. 2008.

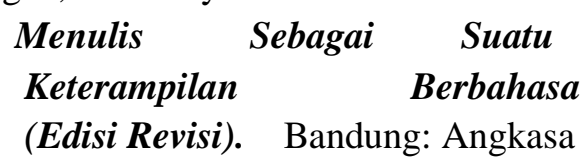


